\title{
Effect of Temperature on Growth and Sporulation of Botrytis fabae, and Resistance Reactions of Faba Bean against the Pathogen
}

\author{
Habtamu Terefe $^{1 *}$, Chemeda Fininsa ${ }^{1}$, Samuel Sahile ${ }^{2}$ and Kindie Tesfaye ${ }^{3}$
}

${ }^{1}$ School of Plant Sciences, Haramaya University, P.O. Box 138, Dire Dawa, Ethiopia

${ }^{2}$ College of Natural and Computational Science, University of Gondar, P.O. Box 196, Gondar, Ethiopia

${ }^{3}$ The International Maize and Wheat Improvement Center (CIMMYT), Addis Ababa, Ethiopia

\begin{abstract}
Chocolate spot (Botrytis fabae) is a devastating disease of faba bean and reduces its production and productivity. Three controlled condition experiments were conducted to assess the effect of temperature on growth and sporulation of $B$. fabae, and faba bean resistance reaction against the pathogen using a single $B$. fabae isolate and Degaga and Bulga-70 faba bean varieties. For cultural experiment, a circular block of actively growing $B$. fabae mycelia was placed on faba bean dextrose agar medium and arranged in a completely randomized design (CRD) with four replications. For resistance reaction evaluation, fresh culture of isolate suspension was prepared $\left(2 \times 10^{5}\right.$ spores $\mathrm{ml}^{-1}$ ) and inoculated on to three weeks-old faba bean seedling detached leaves and the whole plant. Inoculated leaflets and seedlings were factorial arranged in a CRD with four replications. Both sets were incubated at 20, 22, 24 and $26^{\circ} \mathrm{C}$. The maximum $(84.00 \mathrm{~mm})$ radial growth on 5 days after inoculation (DAl); average conidial size $(24.86 \times$ $16.32 \mu \mathrm{m})$, sporulation $\left(2.48 \times 10^{3}\right.$ conidia $\left.\mathrm{ml}^{-1}\right)$ on $12 \mathrm{DAl}$ and growth rate $\left(1.058 \mathrm{~mm} \mathrm{day}{ }^{-1}\right)$ were recorded at $22^{\circ} \mathrm{C}$. The least values of these parameters and nil sporulation were obtained from $26^{\circ} \mathrm{C}$. The highest average lesion size (17.67 $\mathrm{mm}$ in Degaga and $22.83 \mathrm{~mm}$ in Bulga-70), AUDPC for lesion sizes (30.92 mm in Degaga and $42.08 \mathrm{~mm}$ in Bulga-70) and severity ( 2.13 score) values were recorded at $22^{\circ} \mathrm{C}$ on 5DAl in detached leaf test. Infection and disease development was reduced at $26^{\circ} \mathrm{C}$. The trend was similar in the whole plant test. Such parameters were linearly increased with temperature to maximum and declined progressively in both reaction evaluation tests. The two evaluation experiments indicated that the optimum temperature for $B$. fabae growth, sporulation, infection and disease development was at $22^{\circ} \mathrm{C}$.
\end{abstract}

Keywords: Botrytisfabae; Chocolate spot; Detached leaf test; Mycelial growth; Sporulation; Temperature; Vicia faba; Whole plant test

\section{Introduction}

Faba bean (Vicia faba L.) is the third most important food legume in the world [1]. Faba bean has high nutritional value and thus, it is a rich available source of food for human beings and feed for animals [2]. Faba bean is used as an excellent component of crop rotation and green manure to improve soil fertility [3]. Over the last century, however, there has been a steady reduction in the cultivated area of faba bean in many countries due to several reasons. Under Ethiopian conditions, biological limitations include inherently low grain yielding potential of the indigenous cultivars and susceptibility to biotic and abiotic stresses [4]. Among biotic stresses, diseases have always been the major limiting factors for faba bean cultivation. The major ones include ascochyta blight (Ascochyta fabae Speg.), rust [Uromyces viciae-fabae (Pers.) J. SchrÖt.] and chocolate spot (Botrytis fabae Sard.) in Ethiopia [5].

Chocolate spot is an important disease of worldwide distribution, which causes high yield loss [6,7]. The prevalence of chocolate spot in main faba bean growing areas of Ethiopia is about $94.6 \%$ [8] and the disease caused up to $34 \%$ and $61 \%$ yield losses on tolerant and susceptible faba bean varieties, respectively [9]. Sahile et al. [10] reported a yield loss of up to $68 \%$ on the variety CS20DK and the local cultivars of faba bean in northern Ethiopia. A number of factors, such as physiological and environmental conditions, are known to influence plant pathosystems, either by affecting the host, the pathogen, or their interaction [11] and hence crop yield loss. For instance, climate influences the pathogen and host environments separately and in interaction throughout the period of crop growth from infection to host death [12].

Temperature affects plant resistance against a disease due to interactions of temperature with some corresponding gene pairs [13] Sillero et al. [14] reported the interactions of temperature with some Uromyces viciae-fabae:Vicia faba gene combinations. They also showed that host-pathogen pairs responded differently to varying temperatures. It is well known that temperature governs the rate of reproduction of fungi and the physiological conditions of the host and has a marked effect on the incidence of diseases [12]. Temperature also affects the growth and aggressiveness of pathogens and expression of disease symptoms in the plants [15]. Moreover, it has been demonstrated that inoculum density and host physiology have been closely related with temperature and disease development [16]. Thus, plants and pathogens require optimum temperature ranges to grow and carry out their physiological activities. Temperature ranging from 18 to $27^{\circ} \mathrm{C}$ for faba bean growth [17] and between 15 and $23^{\circ} \mathrm{C}$ for $B$. fabae development [18] are reported. Severity of chocolate spot is favored between $92-$ $100 \%$ relative humidity and $15-20^{\circ} \mathrm{C}$ temperature [19].

Although inoculum density, leaf wetness periods, relative humidity and temperature $[5,20]$, host age and resistance reaction [11] influence

*Corresponding author: Habtamu Terefe, School of Plant Sciences, Haramaya University, P.O. Box 138, Dire Dawa, Ethiopia, Tel: +251 910309552; E-mail: habmam21@gmail.com

Received June 10, 2015; Accepted July 02, 2015; Published July 10, 2015

Citation: Terefe H, Fininsa C, Sahile S, Tesfaye K (2015) Effect of Temperature on Growth and Sporulation of Botrytis fabae, and Resistance Reactions of Faba Bean against the Pathogen. J Plant Pathol Microb 6: 285. doi:10.4172/2157 7471.1000285

Copyright: $\odot 2015$ Terefe $\mathrm{H}$, et al. This is an open-access article distributed under the terms of the Creative Commons Attribution License, which permits unrestricted use, distribution, and reproduction in any medium, provided the original author and source are credited. 
development of chocolate spot severity, quantitative relationships among these variables have not been reported. The effect of temperature could be addressed using detached leaf technique [21] and whole plant tests [7] under controlled conditions. A detached leaf test has been widely used for resistance screenings, analyzing components of resistance and assaying different factors affecting the response of $V$. faba to $B$. fabae $[21,22]$. Whole plant screenings are also widely used in the analysis other legume pathosystems [7].

Knowledge of theinteraction of host and pathogen with environment factors has a practical significance because the environment could alter cultivars resistance and pathogen pathogenicity. Moreover, the effect of temperature and other factors on the development of a plant disease after infection depends on the specific host-pathogen combination. The role of leaf wetness, relative humidity, raining frequency and temperature on infectivity and subsequent development of chocolate spot on faba bean has been inferred from field conditions [5], which are difficult to address interaction effects. Climatic dynamics also indicated that temperature affects host resistance; and is known to be of great importance in the process of infection [20,23]. However, its relationship with resistance has hardly been the subject of research; and with regard to faba bean/B. fabae, there are very few studies concerning the relationship between resistance response and temperature [11,24]. In addition, pathogen responses to temperature in vitro may be used as an indirect measure of adaptation to a particular environment [25] and can provide useful information on epidemics development and associated management strategies under rising temperatures of climate change scenarios. Therefore, the objectives of this study were to assess the effects of temperature on the growth and sporulation of $B$. fabae, and resistance reactions in faba bean against $B$. fabae under controlled conditions.

\section{Materials and Methods}

\section{Pathogen isolation and culturing}

The B. fabae isolate used throughout this study was isolated from naturally infected faba bean plants cultivated in Haramaya University (Ethiopia) crop research site that showed typical chocolate spot symptoms. Infected leaflets with advanced margins of chocolate spot lesions were surface-sterilized by $5 \%$ sodium hypochlorite solution for 3 minutes and dried with a sterile blotting paper. The patch specimens were placed on the surface of potato dextrose agar (PDA) medium in Petri dishes [26]. The dishes with 2-3 mm piece of infected leaflets were kept in a glass case at room temperature $\left(18-20^{\circ} \mathrm{C}\right)$ under $12 \mathrm{~h}$ day/ night alternating cycles using fluorescent light and examining them 5-7 days after inoculation for emerging fungal colonies [26]. Following 5-7 days of incubation, fragments of the edges of freshly growing mycelia were transferred into new dishes of faba bean dextrose agar, FDA [27]. The dish with the fungus was again incubated at room temperature (18$20^{\circ} \mathrm{C}$ ) under $12 \mathrm{~h}$ of day/night alternating cycles of light and examined 3-5 days after incubation. The mycelia were sub-cultured several times, until the pure cultures were obtained.

\section{Spore production}

The procedure used by Zakrzewska [27] was followed to produce an abundantly sporulating mycelium. The $B$. fabae pure cultures from FDA medium were transferred to MnPDA medium (PDA medium supplemented with $20 \mathrm{~g}$ of faba bean seed meal per $1 \mathrm{~L}$ of the medium). Petri dishes with the fungus were arranged in stacks and incubated at room temperature, for 3-5 days until the mycelia began to grow. The cultures were exposed to the cycles of $12 \mathrm{~h}$ of light/darkness again to induce sporulation. The dishes with sporulating B. fabae were transferred again to a room with natural light 6 days after such treatment, and they remained there for 4-5 days. In this manner, the ability of sporulation was confirmed before evaluation was commenced.

\section{Evaluation of growth and sporulation of $B$. fabae}

An agar disc, $6 \mathrm{~mm}$ in diameter, was taken from the actively growing margin of 10 days-old culture using a sterile cork borer, and placed in the center of a $9 \mathrm{~cm}$ Petri dish containing $20 \mathrm{ml}$ of FDA. Inoculation was made on MnPDA medium for sporulation evaluation. The inoculated FDA and MnPDA Petri plates were arranged together in completely randomized design with four replications and incubated at four temperature $\left(20,22,24\right.$ and $\left.26^{\circ} \mathrm{C}\right)$ levels. Visual observations were made with regard to colony growth two days after inoculation (DAI). The colony diameters $(\mathrm{mm})$ were measured in two directions at right angles to each other at every $24 \mathrm{~h}$ interval until the mycelium fully covered the Petri dish. Colony morphology, texture and shape were characterized at full plate colony growth (6-10 DAI).

Conidial size, sporulation and sclerotial production were estimated from 12 days-old culture for each temperature level per plate. For conidial size, the length and the width of 30 conidia per sample were measured. Each plate was flooded with $10 \mathrm{ml}$ of sterile distilled water and its entire surface was gently rubbed with a glass rod several times to release all the spores. The spore suspension obtained was filtered through two layers of sterile gauze and was poured into a small beaker, the plate rinsed thoroughly, and the final volume was adjusted to 20 $\mathrm{ml}$ by adding sterile distilled water [28]. Sporulation was determined under the microscope by counting 4 samples $(0.1 \mathrm{ml}$ each) per replicate. Number and size of spores were counted and measured using the Malassez haemacytometer slide and micrometer under an optical microscope field of vision (10x eyepiece and 40x objective), respectively. The experiment was repeated twice.

\section{Evaluation of faba bean resistance reaction against $B$. fabae}

Faba bean varieties Degaga (moderately resistant) and Bulga-70 (susceptible) were used for both detached leaf and whole plant tests to investigate the reaction in both varieties against $B$. fabae at different temperature levels under controlled conditions. Both varieties were collected from Holleta Agricultural Research Center, Ethiopia.

Detached leaf test (Plant material, inoculum, and inoculation): The plant material was prepared by growing the two faba bean varieties in a growth chamber at Plant Protection Laboratory, Haramaya University. Seeds were surface-disinfected in $5 \%$ sodium hypochlorite solution for 3 minutes and rinsed three times with distilled sterile water. Six seeds of each faba bean variety were separately planted in $14 \mathrm{~cm}$ diameter pots filled with a sieved and autoclave-sterilized arable loam soil, peat and sand 3:1:1 (v:v:v) proportion. Germinated seedlings were thinned to four plants per pot. The seedlings were exposed to a temperature of $20 / 16^{\circ} \mathrm{C}$ (day/night) [21] and grown for 3 weeks with a photoperiod of $14 \mathrm{~h}$ of visible light $\left(150 \mu \mathrm{mol} \mathrm{m} \mathrm{m}^{-2} \mathrm{~s}^{-1}\right.$ photon flux density) and $10 \mathrm{~h}$ of darkness [11].

Inoculum was prepared from $B$. fabae previously isolated and maintained as described in Section 2.1. The fungal culture was transferred to chrysanthemum (Chrysanthemum sinense Sabine) flower medium ( $4 \mathrm{~g}$ of dried chrysanthemum flower $+0.5 \mathrm{~g}$ of dextrose $+15 \mathrm{ml}$ of distilled water were blended together in a $250 \mathrm{ml}$ flask. Then the content was autoclaved for 30 minutes) to further induce abundant sporulation. The flasks containing inoculated medium were tightly sealed and left at room temperature $\left(18-20^{\circ} \mathrm{C}\right)$ with alternating cycles 
of $12 \mathrm{~h}$ of light from a $40 \mathrm{~W}$ fluorescent tube and $12 \mathrm{~h}$ of darkness for 13-15 days. A spore suspension was prepared from 15 days-old cultures of the isolate. The spores were dislodged by scraping the surface of the medium with a bent glass rod and a sterile needle and washed out of the surface of the medium with distilled sterile water $(10-15 \mathrm{ml})$. The suspension was filtered through two layers of sterile cheesecloth 30 minutes after stirring, to remove mycelium fragments. The resulting suspension of $B$. fabae spores was adjusted to the concentration of $2 \times$ $10^{5}$ spores $\mathrm{ml}^{-1}$ with the help of a Malassez haemacytometer under 10 fields of optical microscope. Finally, Tween-20 (0.03\% v/v) was added to the suspension.

Leaves of sample plants were collected from each variety two hours prior to inoculation. Fully-expanded leaflets of similar physiological age were excised from the $5^{\text {th }}$ node position and immediately laid flat on a moistened sterile double filter paper immersed in glucose solution $(0.4 \% \mathrm{w} / \mathrm{v})$ laid on sterile $10 \mathrm{~cm}$ Petri plates. Small, humid pieces of cotton were put at the end of the leaflet petioles to maintain cells at maximum turgescence [22]. A drop of $\left(2 \times 10^{5}\right.$ spores $\left.\mathrm{ml}^{-1}\right)$ spore suspension was placed on each half leaflet of each variety. Leaflets inoculated with distilled sterile water served as control. The Petri plates were covered to maintain high moisture, and incubated at room temperature $\left(18-20^{\circ} \mathrm{C}\right)$ over night. Plates were distributed the next day to each separate incubator adjusted at four temperature $(20,22,24$ and $26^{\circ} \mathrm{C}$ ) levels and incubated for six days. The cotton was moistened with $1 \mathrm{ml}$ of distilled sterile water every $24 \mathrm{~h}$ to ensure an environment of high humidity. The experiment was factorial arranged in a CRD with 4 replications (Petri dishes containing two leaflets per faba bean variety). Temperature and variety were considered as main effects and the experiment was repeated twice.

Whole plant test (Plant material, inoculum, and inoculation): Similar procedures were followed related to planting material and inoculum preparation as in Section 2.4.1. Plants of each variety were exposed to each respective temperature level prior to inoculation. Three weeks-old plants (4-6 expanded leaves) were sprayed with $1.5 \mathrm{ml}(2 \times$ $10^{5}$ spores $\mathrm{ml}^{-1}$ ) spore suspension per plant to run-off using an atomizer. The treated pots were factorial arranged in a completely randomized design with four replications and kept in darkness overnight at room temperature in an incubation chamber. Then they were transferred to the experimental run of the growth chamber adjusted at 20,22, 24 and $26^{\circ} \mathrm{C}$ with a photoperiod of $14 \mathrm{~h}$ of visible light and $10 \mathrm{~h}$ of darkness, where the relative humidity was maintained on average over $90 \%$, following the modified procedure of Villegas-Fernandez et al. [11]. The setup was sprayed with a mist of water three times a day to ensure adequate moisture till the end of the trial period. The experiment was not repeated.

Disease assessment: For detached leaf test, leaflets were assessed for their susceptibility to $B$. fabae infection by measuring the expansion of the lesions daily to 5 DAI. Lesion size (LS) was recorded on 3, 4 and 5 DAI. The average lesion size (ALS) was calculated for each leaflet at each evaluation time as the mean of the sizes of lesions of the two leaflets measured. The average measurements of the lesion sizes (considered as a single observation) on the two inoculated leaflets in each Petri dish were used for statistical data analysis. Area under disease progress curve (AUDPC) for lesion sizes was computed for each incubation temperature for both faba bean varieties. AUDPC was determined with the expansion of lesion sizes over time [29] as:

$$
\operatorname{AUDPC}=\sum_{\mathrm{i}=1}^{\mathrm{n}} 1 / 2\left[\left(\mathrm{y}_{\mathrm{i}+1}+\mathrm{y}_{\mathrm{i}}\right)\left(\mathrm{x}_{\mathrm{i}+1}-\mathrm{x}_{\mathrm{i}}\right)\right]
$$

where $\mathrm{x}_{\mathrm{i}}=$ time (days); $\mathrm{y}_{\mathrm{i}}=$ lesion size at the day $\mathrm{i}$; and $\mathrm{n}=$ total number of lesion symptom observations.

Disease severity (DS) assessment was evaluated on 5 DAI using a 1-4 scoring scale [2,7]. In the whole plant test, LS and DS were assessed from nine leaflets per plant starting from 5 DAI. Three plants per pot and four pots per variety were randomly taken for disease parameters assessment. Disease severity recordings were made on 5, 8, 11, 14, 17 and 20 DAI. LS assessments were made on 5, 9, 13, 17 and 21 DAI. The values of each leaflet DS and LS were expressed as means per plant to carry out the statistical analysis. Disease severity was assessed as the percentage of the total leaf surface covered with chocolate spot lesions on each expanded leaflet separately at regular intervals using a 0-9 scale Ding et al. [30], where, $0=$ no visible infection on leaves; $1=\mathrm{a}$ few dot-like accounting for less than $5 \%$ of total leaf area; $3=$ discrete spots less than $2 \mathrm{~mm}$ in diameter (6-25\% of leaf area); $5=$ numerous scattered spots with a few linkages, diameter $3-5 \mathrm{~mm}$ (26-50\% of leaf area) with a little defoliation; $7=$ confluent spot lesions ( $51-75 \%$ of leaf area), mild sporulation, half the leaves dead or defoliated; $9=$ complete destruction of the larger leaves (covering more than $76 \%$ of leaf area), abundant sporulation, heavy defoliation and plants darkened and dead. The DS data were converted to percentage severity index (PSI) according to Wheeler [31]:

\section{PSI $=\quad$ Sum of Numerical Ratings $\times 100$ Number of Plants Scored $\times$ Maximum Score on Scale}

Based on LS and DS data, area under disease progress curve (AUDPC) was computed for size of spots and disease scores according to the formula used by Madden and Hughes [29].

\section{Data analysis}

Data from two runs of experiments were pooled after confirming homogeneity of variances for growth and sporulation evaluation. Analysis of Variance (ANOVA) was performed to determine effects of incubation temperature on colony radial growth rate, sporulation and conidial size. The numbers of conidia $\mathrm{ml}^{-1}$ were analyzed after logarithmic transformation of the values obtained [32]. Regression analysis of diameters of colony radial growth against time after inoculation were performed and the slopes were used as measures of growth rates $\left(\mathrm{mm} \mathrm{day}^{-1}\right)$ for each temperature treatment [33]. For resistance reaction evaluation, data on incubation period, LS, DS and AUDPC for both ALS and DS were analysed using ANOVA, to know the effects of incubation temperature on the growth of the pathogen and development of chocolate spot and faba bean resistance reaction against $B$. fabae. Regression analysis of lesion expansion against time after inoculation was performed and the slope was considered as the measure of rate $\left(\mathrm{mm} \mathrm{day}^{-1}\right)$ of chocolate spot using both detached leaf and whole plant tests [34]. In all cases, ANOVA was run using SAS GLM Procedure [35]. Treatment mean separations were done using the least significant difference (LSD) test at 0.05 probability level. Bartlett's variance homogeneity tests were performed for each variable before combining data over the two runs of experiments both in cultural study and detached leaf test [36].

\section{Results}

\section{Effect of temperature on growth and sporulation of $B$. fabae}

The radial growth, conidial formation and growth rate of the isolate at different incubation temperatures is presented in Table 1 . The results showed a significant $(P \leq 0.05)$ reduction in the mycelial growth at $26^{\circ} \mathrm{C}$ compared to the temperatures at 20,22 and $24^{\circ} \mathrm{C}$. Significant 
difference was measured among incubation temperatures starting from $72 \mathrm{~h}$ after inoculation periods. Radial mycelium growth increased from $27.57 \mathrm{~mm}$ at $26^{\circ} \mathrm{C}$ to $84 \mathrm{~mm}$ at $22^{\circ} \mathrm{C}$ on $120 \mathrm{~h}$ after inoculation. Radial growth rate was affected by temperature. The isolate grew faster $\left(1.058 \mathrm{~mm} \mathrm{day}^{-1}\right)$ at $22^{\circ} \mathrm{C}$ and relatively slower $\left(0.317 \mathrm{~mm}\right.$ day $\left.^{-1}\right)$ at $26^{\circ} \mathrm{C}$ than at other temperatures tested. The radial growth followed a linear increasing trend at each incubation temperature over time (Figure 1).

Mycelial growth patterns included both light and dense extending mycelium. Highly dense mycelium with grey semi-concentric rings associated with black sclerotia was observed at both 20 and $22^{\circ} \mathrm{C}$ at later incubation period. Such characteristics were intermediate at $24^{\circ} \mathrm{C}$, but a very thin mycelium with a very slow extending rate without grey bands (associated with colour of conidia) was obtained at $26^{\circ} \mathrm{C}$. The colony colour was more or less similar at 20,22 and $24^{\circ} \mathrm{C}$ (Figure 2 ). However, very clear grey colouration at the later growth period was observed only at 20 and $22^{\circ} \mathrm{C}$, due to rate of sporulation and distribution of conidia. On the other hand, a very odd whitish colony (composed of white mycelium) was observed nearly in the whole cycle of the incubation period at $26^{\circ} \mathrm{C}$. Growth resumed when inoculum plugs were placed on both FDA and PDA media and incubated at the optimum $\left(22^{\circ} \mathrm{C}\right)$ temperature identified.

The isolate highly $\left(2.476 \times 10^{3} \mathrm{ml}^{-1}\right)$ sporulated at $22^{\circ} \mathrm{C}$ followed by 20 and $24^{\circ} \mathrm{C}$ temperature levels. No sporulation was recorded at $26^{\circ} \mathrm{C}$

\begin{tabular}{|c|c|c|c|c|c|c|c|}
\hline \multirow[t]{2}{*}{$\begin{array}{c}\text { Temperature } \\
\left({ }^{\circ} \mathrm{C}\right)\end{array}$} & \multicolumn{5}{|c|}{$\begin{array}{l}\text { Radial colony growth }(\mathrm{mm}) \text { after different } \\
\text { time periods }(\mathrm{h}) \text { of incubation }{ }^{1}\end{array}$} & \multirow[t]{2}{*}{$\begin{array}{c}\text { Radial growth } \\
\text { rate }(\mathrm{mm} \\
\left.\text { day }^{-1}\right)^{2}\end{array}$} & \multirow[t]{2}{*}{$\mathrm{R}^{2}(\%)$} \\
\hline & 48 & 72 & 96 & 108 & 120 & & \\
\hline 20 & $8.20^{\mathrm{a}}$ & $24.90^{\mathrm{b}}$ & $44.33^{b}$ & $64.60^{\mathrm{b}}$ & $80.67^{b}$ & 0.995 & 96.5 \\
\hline 22 & $8.67^{a}$ & $30.97^{a}$ & $52.43^{a}$ & $73.37^{a}$ & $84.00^{a}$ & 1.058 & 98.6 \\
\hline 24 & $6.77^{a}$ & $22.97^{b}$ & $38.77^{c}$ & $54.70^{c}$ & $69.10^{c}$ & 0.845 & 96.6 \\
\hline 26 & $6.13^{a}$ & $12.07^{c}$ & $21.90^{d}$ & $25.70^{d}$ & $27.57^{d}$ & 0.317 & 94.7 \\
\hline Mean & 7.44 & 22.73 & 39.36 & 54.59 & 65.34 & 0.804 & \\
\hline LSD $(0.05)$ & 2.80 & 4.30 & 4.56 & 4.57 & 2.89 & & \\
\hline CV (\%) & 20.0 & 10.05 & 6.15 & 4.45 & 2.35 & & \\
\hline
\end{tabular}

Table 1: In vitro effect of incubation temperature $\left({ }^{\circ} \mathrm{C}\right)$ on radial colony growth $(\mathrm{mm})$ and radial growth rate $\left(\mathrm{mm}^{-1}\right.$ day $\left.^{-1}\right)$ of Botrytis fabae cultured on faba bean dextrose agar (FDA) medium, and conidial formation of $B$. fabae isolate cultured on MnPDA ${ }^{1}$ Radial growth was determined as average of two runs of experiments on radial colony growth of $B$. fabae.

${ }^{2}$ Linear radial growth rates were estimated as the slope of the following function: Colony diameter $=$ Radial growth rate $x$ time $+b$.

Means of colony radial growth in the same column followed by the same letters are not significantly different $(P \leq 0.05)$. The values in the table are based on untransformed data of radial mycelial growth from two runs of experiments.

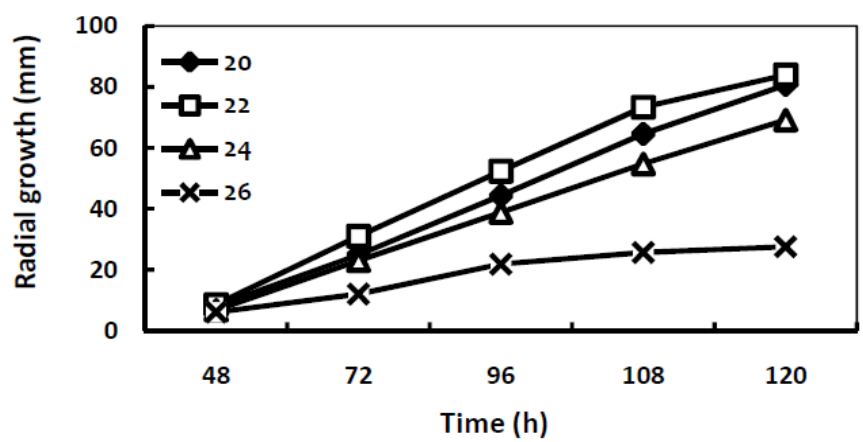

Figure 1: In vitro effect of incubation temperature $\left({ }^{\circ} \mathrm{C}\right)$ on radial colony growth of Botrytis fabae on faba bean dextrose agar (FDA) medium (values are means of pooled data from two runs of the experiment).

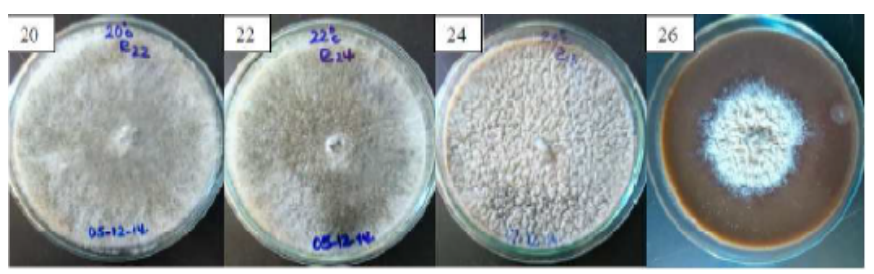

Figure 2: In vitro effect of incubation temperature $\left({ }^{\circ} \mathrm{C}\right)$ on morphology (conidation and colour) of Botrytis fabae on MnPDA medium 10 days after inoculation and incubation.

\begin{tabular}{|c|c|c|c|c|c|c|}
\hline \multirow{2}{*}{$\begin{array}{c}\text { Temperature } \\
\left({ }^{\circ} \mathrm{C}\right)\end{array}$} & \multicolumn{5}{|c|}{ Sporulation $\left(\times 10^{3} / \mathrm{ml}\right)^{2}$} \\
\cline { 2 - 7 } & \multicolumn{2}{|c|}{ Length } & \multicolumn{2}{|c|}{ Width } & Rough & $\begin{array}{c}\text { Transformed } \\
\text { data }\end{array}$ \\
\hline & Mean & Range $^{3}$ & Mean & Range $^{3}$ & \\
\hline 20 & $20.24^{\mathrm{b}}$ & $16.47-23.53$ & $13.18^{\mathrm{b}}$ & $11.77-14.12$ & 266 & $2.426^{\mathrm{b}}$ \\
\hline 22 & $24.86^{\mathrm{a}}$ & $21.18-28.24$ & $16.32^{\mathrm{a}}$ & $11.77-18.82$ & 298 & $2.476^{\mathrm{a}}$ \\
\hline 24 & $19.54^{\mathrm{c}}$ & $13.79-22.99$ & $11.58^{\mathrm{c}}$ & $6.90-18.39$ & 202 & $2.307^{\mathrm{c}}$ \\
\hline 26 & $0.00^{\mathrm{d}}$ & - & $0.00^{\mathrm{d}}$ & - & 0 & $0.000^{\mathrm{d}}$ \\
\hline LSD (0.05) & 0.26 & & 0.35 & & & 0.022 \\
\hline CV (\%) & 1.06 & & 2.21 & & & 0.658 \\
\hline
\end{tabular}

Table 2: In vitro effect of incubation temperature $\left({ }^{\circ} \mathrm{C}\right)$ on conidial size $(\mu \mathrm{m})$ and sporulation of Botrytis fabae isolate cultured on MnPDA medium.

${ }^{1}$ Average of 30 readings.

${ }^{2}$ Conidial production/sporulation was observed 12 days after inoculation. Variables "Sporulation $\mathrm{ml}^{-1}$ (x 1000)" were analysed after logarithmic transformation [log (x $+1)]$.

${ }^{3}$ Indicated absence of sporulation and hence, no conidial dimension record at 26 ${ }^{\circ} \mathrm{C}$.

Means of conidial dimensions in the same column followed by the same letters are not significantly different $(P \leq 0.05)$.

on 12 DAI (Table 2). The mean size of conidia varied both in length and width. The conidial length of the isolate ranged from 21.18 to 28.24 $\mu \mathrm{m}$ while conidial width ranged from 11.77 to $18.82 \mu \mathrm{m}$ at $22^{\circ} \mathrm{C}$. The longest $(24.86 \mu \mathrm{m})$ mean conidial length and the widest $(16.32 \mu \mathrm{m})$ mean conidial thickness were measured from the isolate incubated at $22^{\circ} \mathrm{C}$ (Table 2).

\section{Effect of temperature on faba bean resistance reaction against Botrytis fabae}

Detached leaf test: First characteristic symptoms of chocolate spot lesions appeared at the site of inoculation $24 \mathrm{~h}$ after inoculation on both faba bean varieties, especially on Bulga-70 at 20, 22 and $24^{\circ} \mathrm{C}$. Forty eight hours after inoculation, LS aggressively increased on leaflets at the first three temperature levels on both faba bean varieties. At these temperatures, lesions enlarged rapidly and centrally deep black with brown margin spots that fused with time to form larger lesions. However, at $26^{\circ} \mathrm{C}$, only water-soaked-like symptoms, which were followed by clear and visible symptoms, were seen with growing lesions $96 \mathrm{~h}$ after inoculation. The incubation period (IP) was relatively longer at $26^{\circ} \mathrm{C}$ and appeared shorter at 20 to $24^{\circ} \mathrm{C}$ but did not show any significant variation among incubation temperatures and between varieties (data not shown)

Lesion sizes on leaflets of both inoculated faba bean varieties showed significant $(P \leq 0.05)$ differences among incubation temperatures, between varieties and temperature $\times$ variety interaction for ALS and AUDPC for lesion sizes starting from $72 \mathrm{~h}$ after inoculation (Table 3 ). The variety Degaga showed significantly smaller lesions and AUDPC values than those expressed by Bulga-70 variety at all incubation temperature levels. The highest ALS and AUDPC values on both varieties were recorded from $22^{\circ} \mathrm{C}$ on all recording DAI. On $5 \mathrm{DAI}$, the 
Citation: Terefe H, Fininsa C, Sahile S, Tesfaye K (2015) Effect of Temperature on Growth and Sporulation of Botrytis fabae, and Resistance Reactions of Faba Bean against the Pathogen. J Plant Pathol Microb 6: 285. doi:10.4172/2157-7471.1000285

Page 5 of 9

\begin{tabular}{|c|c|c|c|c|c|c|c|c|c|c|}
\hline \multirow{3}{*}{$\begin{array}{l}\text { Temperature } \\
\left({ }^{\circ} \mathrm{C}\right)\end{array}$} & \multicolumn{5}{|c|}{ Average lesion size $(\mathrm{mm})$} & \multicolumn{5}{|c|}{ Average lesion size (mm) } \\
\hline & \multicolumn{5}{|c|}{ Degaga } & \multicolumn{5}{|c|}{ Bulga-70 } \\
\hline & $72 \mathrm{~h}$ & $96 \mathrm{~h}$ & $120 \mathrm{~h}$ & AUDPC $^{1}$ & Rate $^{2}$ & $72 \mathrm{~h}$ & $96 \mathrm{~h}$ & $120 \mathrm{~h}$ & AUDPC $^{1}$ & Rate $^{2}$ \\
\hline 20 & $11.83^{\mathrm{bcd}}$ & $13.83^{\mathrm{bc}}$ & $15.50^{\mathrm{bc}}$ & $27.50^{\mathrm{bc}}$ & 0.099 & $16.17^{a}$ & $20.50^{\mathrm{a}}$ & $22.33^{a}$ & $39.75^{a}$ & 0.173 \\
\hline 22 & $12.83^{\mathrm{bc}}$ & $15.67^{b}$ & $17.67^{b}$ & $30.92^{b}$ & 0.132 & $17.33^{\mathrm{a}}$ & $22.00^{\mathrm{a}}$ & $22.83^{a}$ & $42.08^{a}$ & 0.159 \\
\hline 24 & $10.50^{d}$ & $11.83^{\text {cd }}$ & $14.67^{c}$ & $24.42^{\circ}$ & 0.107 & $13.17^{\mathrm{b}}$ & $15.17^{b}$ & $17.83^{b}$ & $30.67^{b}$ & 0.123 \\
\hline 26 & $8.17^{\mathrm{e}}$ & $10.00^{d}$ & $10.83^{d}$ & $19.50^{d}$ & 0.074 & $10.83^{c d}$ & $13.50^{\mathrm{bc}}$ & $14.83^{c}$ & $26.33^{\mathrm{bc}}$ & 0.111 \\
\hline Mean & 10.83 & 12.83 & 14.67 & 25.59 & 0.103 & 14.38 & 17.79 & 19.46 & 34.71 & 0.142 \\
\hline CV (\%) & 21.90 & 21.92 & 18.26 & 19.51 & & 21.90 & 21.92 & 18.26 & 19.51 & \\
\hline LSD (0.05) & $* *$ & ** & $* *$ & ** & & $* *$ & $* *$ & ** & ** & \\
\hline
\end{tabular}

Table 3: In vitro effect of incubation temperature $\left({ }^{\circ} \mathrm{C}\right)$ on reactions of two faba bean varieties against Botrytis fabae using detached leaf test.

${ }^{1}$ Area under disease progress curves for lesion sizes of chocolate spot in the detached leaf test.

${ }^{2}$ Linear lesion size expansion rates were estimated as the slope of the following function: Lesion diameter $=a+$ Lesion growth rate $x$ time (based on untransformed data).

** The presence of highly significant difference at $P \leq 0.05$ probability level.

Means of lesion size and AUDPC in the same column with the same letters are not statistically different $(P \leq 0.05)$. The values in the table are based on untransformed data of lesion expansion from two runs of experiments.

highest $(22.83 \mathrm{~mm})$ ALS and AUDPC (42.08 mm-days) were obtained from $22^{\circ} \mathrm{C}$ on Bulga-70. Comparably, the highest $(17.67 \mathrm{~mm}) \mathrm{ALS}$ and AUDPC (30.92 mm-days) were recorded from the same temperature level on Degaga variety. The lowest values of both parameters were recorded from $26^{\circ} \mathrm{C}$ and un-inoculated control of both varieties. The ALS and AUDPC values increased from 20 to $22^{\circ} \mathrm{C}$ with significant differences between the varieties and decreased as temperature increased beyond $22^{\circ} \mathrm{C}$.

The rate of lesion growth increased rapidly on Bulga-70 as compared to the variety Degaga. The average rate of lesion expansions varied from $0.0744 \mathrm{~mm} \mathrm{day}^{-1}$ at $26^{\circ} \mathrm{C}$ to $0.132 \mathrm{~mm}^{-1 a y}{ }^{-1}$ at $22^{\circ} \mathrm{C}$ on variety Degaga and from $0.111 \mathrm{~mm} \mathrm{day}^{-1}\left(26^{\circ} \mathrm{C}\right)$ to $0.173 \mathrm{~mm} \mathrm{day}^{-1}\left(20^{\circ} \mathrm{C}\right)$ on variety Bulga-70 (Table 3). Reaction differences between varieties and among incubation temperatures in disease severity scores became significantly $(P \leq 0.05)$ different on $120 \mathrm{~h}(5 \mathrm{DAI})$ (Table 4$)$. Chocolate spot severity on both faba bean varieties was also significantly different from their respective un-inoculated controls (which were scored 1 on the scale) but without any significant interaction effect. The highest (2.13) mean severity was scored at $22^{\circ} \mathrm{C}$ and the lowest $(1.67)$ was at $26^{\circ} \mathrm{C}$. In all the incubation temperatures studied, the variety Bulga-70 had higher mean chocolate spot severity than the variety Degaga.

Whole plant test: Faba bean plants inoculated with B. fabae conidia during seedling stages and maintained at different incubation temperature levels developed chocolate spot symptoms. All infected plants showed typical symptoms of small brown necrotic flecks clearly visible on leaves by the next DAI, which evolved into typical chocolate spot lesions $24 \mathrm{~h}$ later on both faba bean varieties at 20, 22, and $24^{\circ} \mathrm{C}$. Small necrotic flecks appeared $32 \mathrm{~h}$ after inoculation on the variety Bulga-70 and on $48 \mathrm{~h}$ after inoculation on the variety Degaga at $26^{\circ} \mathrm{C}$. Aggressive lesions (which were developed progressively and the nearby smaller flecks of spots begin to coalesce) were visible $48 \mathrm{~h}$ after inoculation on both varieties at 20,22 and $24^{\circ} \mathrm{C}$. Symptoms appeared earlier at both 20 and $22^{\circ} \mathrm{C} 16 \mathrm{~h}$ after inoculation. In contrast, it took slightly longer $(24 \mathrm{~h})$ for symptoms to develop at $24^{\circ} \mathrm{C}$ and $48 \mathrm{~h}$ and more at $26^{\circ} \mathrm{C}$ after inoculation (data not shown). No control plants developed chocolate spot symptoms. There was no infection observed on new leaves that emerged after the plants were inoculated.

The lesion development and percent leaf damage by the $B$. fabae isolate on the two faba bean varieties showed a significant $(P \leq 0.05)$ variation among incubation temperatures, varieties and variety $\times$ temperature interaction for ALS, mean DS and AUDPC (Tables 5 and 6). The lesion growth was least on both faba bean varieties at $26^{\circ} \mathrm{C}$, $1.45 \mathrm{~mm}$ (Degaga) and $1.47 \mathrm{~mm}$ (Bulga-70) on 21 DAI. The highest
(2.89 $\mathrm{mm}$ on Degaga and $6.33 \mathrm{~mm}$ on Bulga-70) mean values of lesion sizes were recorded on $21 \mathrm{DAI}$ at $22^{\circ} \mathrm{C}$. AUDPC for lesion sizes ranged from 25.43 to $46.85 \mathrm{~mm}$-days (Degaga) and 27.49 to $113.89 \mathrm{~mm}$-days (Bulga-70). The variety Bulga-70 had the largest $(6.33 \mathrm{~mm}) \mathrm{ALS}$ at $22^{\circ} \mathrm{C}$ on 21 DAI while the lowest $(2.89 \mathrm{~mm})$ ALS was measured from the variety Degaga at the same temperature and DAI.

The final mean DS values ranged from 14.79 to $21.61 \%$ for Degaga and 20.37 to $32.10 \%$ for Bulga-70 on 20 DAI (Table 6). The overall final mean DS at all incubation temperatures revealed that Bulga-70 scored the highest $(26.70 \%)$ DS than Degaga, which scored $17.74 \%$ on 20 DAI. Both faba bean varieties showed similar trends in DS progress, in which DS increased from 20 to $22^{\circ} \mathrm{C}$ and decreased beyond 22 to $26^{\circ} \mathrm{C}$. Similarly, the AUDPC values for severity exhibited a similar trend to DS in that the highest (361.75\%-days on Degaga and $556.81 \%$-days on Bulga-70) AUDPC values for severity were recorded at $22^{\circ} \mathrm{C}$. Progress of chocolate spot on whole plants was much slower than in experiment on excised leaves. The disease progress rates were significantly lower on the variety Degaga than on Bulga-70 at all incubation temperatures. Moreover, significant variety $\times$ temperature interactions for the studied disease parameters indicated that the inherent ability of varieties to express resistance reaction against $B$. fabae was not the same at all incubation temperatures.

\section{Discussion}

This study has indicated differences in the effects of temperatures on mycelial growth, sporulation, conidial size, sclerotial formation and morphology of B. fabae. Radial growth, sporulation, conidial size and sclerotial formation of the fungus increased with increase in temperature and reached maximum at $22^{\circ} \mathrm{C}$ but progressively declined thereafter. However, no sporulation was detected at $26^{\circ} \mathrm{C}$. Effects of temperature on pathogenic fungi growth, sporulation, sclerotial formation and morphology is well documented [37,38]. Fernández et al. [39] found that temperature highly affected the mycelial growth of B. cinerea isolates and discriminate isolates based on their temperature optima. Pefoura et al. [32] showed that radial growth of Trachysphaera fructigena decreased to minimum at higher temperatures, which can be considered as lethal for radial growth of the pathogen. The investigators found that sporulation increased to optimum temperature and then declined till nil at higher temperature levels.

Similarly, Sehajpal and Singh [40] noted that temperature of 20 $\pm 1^{\circ} \mathrm{C}$ was the best for mycelial growth of Botrytis gladiolorum; the least was observed at $30 \pm 1{ }^{\circ} \mathrm{C}$. No conidial and sclerotial production was recorded at lower and extreme temperatures. The rate of mycelial 


\begin{tabular}{|c|c|}
\hline Treatment & Severity(score) \\
\hline Variety & $3.17^{\mathrm{a}}$ \\
\hline Bulga-70 & $2.42^{\mathrm{b}}$ \\
\hline Degaga & $1.00^{\mathrm{c}}$ \\
\hline Control & 2.20 \\
\hline Mean & 0.25 \\
\hline LSD $(0.05)$ & \\
\hline Temperature $\left({ }^{\circ} \mathrm{C}\right)$ & $1.96^{\mathrm{ab}}$ \\
\hline 20 & $2.13^{\mathrm{a}}$ \\
\hline 22 & $1.83^{\mathrm{bc}}$ \\
\hline 24 & $1.67^{\mathrm{c}}$ \\
\hline 26 & 1.90 \\
\hline Mean & 0.25 \\
\hline LSD $(0.05)$ & 15.70 \\
\hline CV $(\%)$ & \\
\hline
\end{tabular}

Table 4: In vitro effect of incubation temperature $\left({ }^{\circ} \mathrm{C}\right)$ on resistance reactions of faba bean (Vicia faba) against Botrytis fabae isolate using detached leaf test on two faba bean varieties.

Mean disease severity based on $1-4$ rating scale for detached leaf test $[7,27]$ where $1=$ highly resistant, no infection or very small flecks (1-25\% necrosis); 2 = resistant, necrotic flecks with few small lesions (26-50\% necrosis), and very poor sporulation 3 = moderately resistant, medium coalesced lesions (51-75\% necrosis) with intermediate sporulation; and 4 = susceptible, large coalesced lesions $(76-100 \%$ necrosis) with abundant sporulation.

Means of leaf disease severity of the same letters are not statistically different $(P \leq 0.05)$.

\begin{tabular}{|c|c|c|c|c|c|c|c|c|}
\hline \multirow{3}{*}{$\begin{array}{c}\text { Faba bean } \\
\text { variety }\end{array}$} & \multirow{3}{*}{$\begin{array}{l}\text { Temperature } \\
\left({ }^{\circ} \mathrm{C}\right)\end{array}$} & \multicolumn{7}{|c|}{ Average lesion size (mm) } \\
\hline & & \multicolumn{7}{|c|}{ Days after inoculation, DAI } \\
\hline & & 5 & 9 & 13 & 17 & 21 & AUDPC $^{1}$ & Rate $^{2}$ \\
\hline \multirow{6}{*}{ Degaga } & 20 & $1.61^{d}$ & $1.78^{d}$ & $1.92^{\mathrm{d}}$ & $2.50^{c}$ & $2.73^{d}$ & $41.81^{d}$ & 0.295 \\
\hline & 22 & $2.01^{c}$ & $2.12^{\mathrm{c}}$ & $2.22^{\mathrm{c}}$ & $2.58^{\mathrm{c}}$ & $2.89^{\mathrm{c}}$ & $46.85^{\mathrm{c}}$ & 0.221 \\
\hline & 24 & $1.08^{\mathrm{e}}$ & $1.17^{\mathrm{fg}}$ & $1.25^{f}$ & $1.36^{\mathrm{e}}$ & $2.14^{f}$ & $26.94^{\mathrm{fg}}$ & 0.231 \\
\hline & 26 & $0.83^{f}$ & $1.06^{g}$ & $1.45^{\mathrm{e}}$ & $1.45^{\mathrm{e}}$ & $1.45^{\mathrm{g}}$ & $25.43^{g}$ & 0.161 \\
\hline & Mean & 1.38 & 1.53 & 1.71 & 1.97 & 2.30 & 35.26 & 0.227 \\
\hline & 20 & $4.08^{b}$ & $4.97^{\mathrm{b}}$ & $5.39^{b}$ & $5.72^{\mathrm{b}}$ & $5.86^{b}$ & $105.28^{b}$ & 0.431 \\
\hline \multirow{6}{*}{ Bulga-70 } & 22 & $4.58^{\mathrm{a}}$ & $5.30^{\mathrm{a}}$ & $5.92^{\mathrm{a}}$ & $6.11^{\mathrm{a}}$ & $6.33^{\mathrm{a}}$ & $113.89^{\mathrm{a}}$ & 0.429 \\
\hline & 24 & $1.19^{e}$ & $1.61^{\mathrm{e}}$ & $1.97^{\mathrm{d}}$ & $2.19^{d}$ & $2.55^{\mathrm{e}}$ & $38.26^{e}$ & 0.331 \\
\hline & 26 & $1.14^{\mathrm{e}}$ & $1.25^{f}$ & $1.47^{\mathrm{e}}$ & $1.47^{\mathrm{e}}$ & $1.47^{\mathrm{g}}$ & $27.49^{f}$ & 0.089 \\
\hline & Mean & 2.75 & 3.28 & 3.69 & 3.87 & 4.05 & 71.23 & 0.320 \\
\hline & CV (\%) & 10.69 & 9.58 & 9.11 & 7.38 & 5.85 & 4.70 & \\
\hline & LSD (0.05) & ** & $* *$ & $* *$ & $* *$ & $\star *$ & $* *$ & \\
\hline
\end{tabular}

Table 5: In vitro effect of incubation temperature $\left({ }^{\circ} \mathrm{C}\right)$ on lesion size of two faba bean varieties against Botrytis fabae using whole plant test.

${ }^{1}$ Area under disease progress curves of lesion size of chocolate spot in the whole plant test.

${ }^{2}$ Linear lesion size expansion rates were estimated as the slope of linear regression of the following function: Lesion diameter $=a+$ Lesion growth rate $x$ time (based on untransformed data).

** The presence of highly significant difference at $P \leq 0.05$ probability level.

Means of lesion sizes and AUDPC in the same column followed by the same letters are not statistically different $(P \leq 0.05)$. Values are based on untransformed data.

growth of Sphaeropsis pyriputrescens increased as temperature increased up to $20^{\circ} \mathrm{C}$ and then decreased rapidly as temperature increased. Slight changes in colony morphology were observed at lower and higher temperatures than the optimum temperature [41]. Fernando et al. [42] also reported that Corynespora cassiicola sporulated freely on PDA at 10 to $35^{\circ} \mathrm{C}$ with a peak at $30^{\circ} \mathrm{C}$. However, no sporulation or growth of the colonies of the isolates was observed at temperatures below 5 and above $35^{\circ} \mathrm{C}$.

This study demonstrated that temperature also strongly influenced infection due to $B$. fabae and development of chocolate spot in faba bean. Temperature affected incubation period, lesion expansion, percent leaf damage, AUDPC and rate of chocolate spot progress on both detached leaf and whole plant tests in faba bean. When temperature was raised from 20 to $22^{\circ} \mathrm{C}$, lesion expansion, percent leaf damage and AUDPC linearly increased, while these parameters decreased with increase in temperature beyond $22^{\circ} \mathrm{C}$. Incubation period was delayed at the highest $\left(26^{\circ} \mathrm{C}\right)$ temperature tested. Tu [43] found that disease severity in beans inoculated with Colletotrichum lindemuthianum was greater at temperatures ranging from 20 to $24^{\circ} \mathrm{C}$ than at lower or higher temperatures. Disease severity in round-leaved mallow inoculated with Colletotrichum gloeosporioides [44] and in soybean infected with Colletotrichum truncatum [45] increased with increase in temperatures between 10 and $25^{\circ} \mathrm{C}$ and sharply decreased at $30^{\circ} \mathrm{C}$. With regard to incubation period, $\mathrm{Xu}[46]$ and $\mathrm{Xu}$ and Robinson [47] noted that the median incubation period was longer at lower and higher temperatures than at intermediate temperature ranges in rose and hawthorn powdery mildew.

Concerning such optimum-type relationships between lesion sizes and temperature levels, similar results were found by Kuruppu and Schneider [48] who reported that lesion development of aerial blight in soybean increased with increasing temperature (from 21 to $29^{\circ} \mathrm{C}$ ) but decreased at $33^{\circ} \mathrm{C}$, where lesions did not develop at all at $37^{\circ} \mathrm{C}$ or above during day temperatures in growth chambers with high humidity. Pedersen and Morrall [49] reported that lesion counts due to ascochya blight in lentil indicated that the optimal temperature for infection ranged from 10 to $15^{\circ} \mathrm{C}$ and that very little infection occurred at $25^{\circ} \mathrm{C}$ and it appeared to be less favorable for disease development than the lower temperatures. Similarly, lesions of Cercosporidium personata leaf spot of peanut on detached leaves of all genotype were largest, developed most rapidly, and sporulated most profusely at $24^{\circ} \mathrm{C}$. Few infections occurred at 28 and $32^{\circ} \mathrm{C}$ regardless of duration of the high relative humidity [50].

In the whole plant test of this study, plants grown at $26^{\circ} \mathrm{C}$ also showed heat scorching, stunting, marginal diebacks of leaflets, and rapid senesces even without disease symptoms. These findings suggest that this temperature regime might have adversely affected the physiology and growth of the plants, and that the reduction in lesion size and disease severity might not be due to increased resistance. Chongo

\begin{tabular}{|c|c|c|c|c|c|c|c|c|}
\hline \multirow{3}{*}{$\begin{array}{c}\text { Faba } \\
\text { bean } \\
\text { variety }\end{array}$} & \multirow{3}{*}{$\begin{array}{c}\text { Temperature } \\
\left({ }^{\circ} \mathrm{C}\right)\end{array}$} & \multicolumn{7}{|c|}{ Leaf area damage (\%) } \\
\hline & & \multicolumn{7}{|c|}{ Days after inoculation, DAI } \\
\hline & & 5 & 8 & 11 & 14 & 17 & 20 & AUDPC $^{1}$ \\
\hline & 20 & $14.20^{\mathrm{bc}}$ & $14.81^{\mathrm{cd}}$ & $15.43^{\text {de }}$ & $17.28^{d}$ & $17.28^{\mathrm{e}}$ & $18.52^{\mathrm{e}}$ & $324.69^{e}$ \\
\hline & 22 & $16.05^{\mathrm{b}}$ & $16.67^{\mathrm{bc}}$ & $17.29^{d}$ & $17.90^{\mathrm{d}}$ & $19.76^{d}$ & $21.61^{\mathrm{d}}$ & $361.75^{d}$ \\
\hline \multirow[t]{5}{*}{ Degaga } & 24 & $12.35^{\mathrm{cd}}$ & $12.96^{\mathrm{de}}$ & $12.96^{f}$ & $14.82^{\mathrm{ef}}$ & $15.43^{f}$ & $16.05^{f}$ & $281.48^{f}$ \\
\hline & 26 & $11.11^{\mathrm{d}}$ & $11.73^{\mathrm{d}}$ & $12.35^{f}$ & $12.96^{f}$ & $14.81^{f}$ & $14.79^{f}$ & $259.26^{f}$ \\
\hline & Mean & 13.43 & 14.04 & 14.51 & 15.74 & 16.82 & 17.74 & 306.80 \\
\hline & 20 & $19.14^{\mathrm{a}}$ & $23.46^{\mathrm{a}}$ & $24.08^{b}$ & $25.93^{b}$ & $27.78^{b}$ & $29.63^{b}$ & $502.50^{\mathrm{b}}$ \\
\hline & 22 & $20.37^{a}$ & $25.31^{a}$ & $26.55^{\mathrm{a}}$ & $29.63^{a}$ & $31.48^{\mathrm{a}}$ & $32.10^{\mathrm{a}}$ & $556.81^{a}$ \\
\hline \multirow[t]{5}{*}{ Bulga-70 } & 24 & $16.05^{\mathrm{b}}$ & $18.52^{b}$ & $20.37^{c}$ & $22.84^{\mathrm{c}}$ & $24.69^{c}$ & $24.69^{\circ}$ & $427.19^{c}$ \\
\hline & 26 & $11.73^{d}$ & $13.58^{\mathrm{de}}$ & $14.17^{\text {ef }}$ & $16.05^{\text {de }}$ & $19.14^{d}$ & $20.37^{d}$ & $315.95^{e}$ \\
\hline & Mean & 16.82 & 20.22 & 21.29 & 23.61 & 25.77 & 26.70 & 450.61 \\
\hline & CV (\%) & 20.00 & 20.39 & 18.05 & 16.70 & 8.86 & 10.90 & 12.75 \\
\hline & LSD (0.05) & $* *$ & ** & ** & ** & $* *$ & & ** \\
\hline
\end{tabular}

Table 6: In vitro effect of incubation temperature $\left({ }^{\circ} \mathrm{C}\right)$ on leaf area damage (severity) of two faba bean varieties against Botrytis fabae using whole plant test ${ }^{1}$ Area under disease progress curves of percent disease severity of chocolate spot in the whole plant test.

${ }^{* *}$ The presence of highly significant difference at $P \leq 0.05$ probability level.

Means of disease severity and AUDPC in the same column followed by the same letters are not statistically different $(P \leq 0.05)$. 
and Bernier [51] observed a similar pattern in beans inoculated with Colletotrichum lindemuthianum at higher temperatures. The nearly complete inhibition of infection and development of chocolate spot on faba bean at higher $\left(26^{\circ} \mathrm{C}\right)$ temperature was unexpected. However, increasing temperature could affect the pathogen to produce more propagules for subsequent infection and thus conidia must survive exposures to high temperature and low relative humidity that occur between deposition and favorable infection periods.

The current study pointed out that the most optimum temperature for $B$. fabae growth and sporulation as well as chocolate spot infection and development was between 20 and $22^{\circ} \mathrm{C}$. In fact, temperatures around $22^{\circ} \mathrm{C}$ are near those existing in the high prevalence zones of the disease in Ethiopia where the study was conducted under natural conditions. The absence of sporulation and its reduced radial growth, infection and disease development at $26^{\circ} \mathrm{C}$ could explain the reduced pathogenicity at this temperature; but interactions are more complex in the natural environment where multiple climatological and biological factors vary simultaneously [52]. Harrison [20] indicated that B. fabae normally infects faba bean when temperatures are mild $\left(15-22^{\circ} \mathrm{C}\right)$ with high relative humidity; and the most risk factors associated with chocolate spot infection under field conditions include mild temperature $\left(20^{\circ} \mathrm{C}\right)$ and humid conditions [53]. Dereje [18] also found that humid and warm $\left(10-23^{\circ} \mathrm{C}\right)$ with frequent rainy weather conditions are favorable for the development of chocolate spot epidemics, and progression rate reduces late in the season.

Reduced infection and disease development in the present study could be due to several factors including inhibition of mycelial growth and spore mortality at higher temperatures, genetic background of the faba bean varieties used, isolate virulence, leaf-wetness duration, and the interaction among such factors. Higher temperature during epidemic development could also affect the pathogen's ability to produce more propagules. Previous studies showed that an increase in temperature beyond the optimum decreases pustule production on leek leaves by Puccinia allii infection, suggesting that high spore densities were required for successful infection at higher temperatures [54]. In strawberry leaves inoculated with Colletotrichum acutatum conidia and incubated at different temperatures with continuous wetness, the number of germinated conidia tended to decrease with increasing temperature due to cell lysis [55]. Xu [46] also found that low rate of disease development in rose powdery mildew at supraoptimal temperatures is likely due to higher mortality of spores.

Moreover, Christiansen and Lewis [56] indicated that when high-temperature stress is exacerbated, plants show symptoms including wilting, leaf burn, leaf folding, and abscission, and changes in physiological responses. Such changes are expected to occur in the current and future climate dynamics. These changes will certainly affect susceptibility to pathogens, though the wide range of changes may make interactions difficult to predict; and challenging to discriminate between temperature effects on host resistance genes versus effects on pathogen virulence [23]. Hence, we did not directly attempt to partition the effect of temperature on the pathogen virulence gene(s) versus the faba bean resistance gene(s). Rather to the host-pathogen interaction and these have to be further elucidated with known resistance gene(s) in the host and virulence gene(s) in the pathogen using a wide range of temperature levels and other environmental factors. In connection with the impact of temperature on resistance expression, Fetch [57] noted the loss of resistance genes in oat lines at higher temperature and that observation on rust reaffirms the complex interaction between host, pathogen, and environment that determine the host response to pathogen infection. Similarly, in leaf rust-wheat combination under variable temperatures, a change in reaction may neither be a direct response to temperature on the part of the host's resistance alone nor on the part of the parasite's pathogenicity genes alone. Thus, temperature most likely affects the host-parasite interaction [58].

\section{Conclusions}

The current results indicated that temperature strongly influenced growth and sporulation of $B$. fabae and infection and development of chocolate spot in faba bean varieties. Resistance reactions in both faba bean varieties against $B$. fabae appeared temperature dependent. Temperature at $22^{\circ} \mathrm{C}$ was the optimum temperature for the growth, sporulation, infection and disease development; whereas, low disease infection and nil sporulation were recorded at $26^{\circ} \mathrm{C}$. Infection and disease development were more severe on detached leaf than on the whole plants inoculated. Both detached leaf and whole plant tests were promising tools for assessing the response of faba bean plants to $B$. fabae under different incubation temperatures. The methods are also useful for studying various aspects of chocolate spot and behavior of $B$. fabae under controlled conditions to elucidate epidemiological attributes under natural conditions. Such studies can improve our understanding of conditions required for epidemic onset, disease progress rate over time and eventual decline of epidemics; and could allow us to predict the initiation and potential severity of chocolate spot epidemics in the growing season. Absence of sporulation and highly reduced disease levels at $26^{\circ} \mathrm{C}$ seem to imply that the projected temperature rise by $2.1^{\circ} \mathrm{C}$ in Ethiopia my disfavor B. fabae pathogenicity; and may not be a threat to faba bean production in the highland agro-ecologies of Ethiopia in the future climate change scenarios. However, it is difficult to exactly predict the effect of increasing temperature on the host/pathogen and their interactions under controlled conditions. Rising temperature is a gradual process that gives time-window for adjustment and interaction with other dynamic climate variables may influence the effect of temperature. Therefore, investigations on the effects of temperature on infection and disease development in faba bean due to $B$. fabae has to be further tested in greenhouse conditions to enable valid comparisons with field conditions. Moreover, thorough investigations on influence of temperature on the pathogen virulence gene, host resistance gene and on host-pathogen interactions have to be elucidated with known host resistance gene(s) and pathogen virulence gene(s) using a wide range of host cultivars, pathogen isolates, temperature levels and other environmental factors as well as their interactions.

\section{Acknowledgments}

The study was financed by the Swedish International Development Agency (SIDA), Sweden and Haramaya University, Ethiopia. We are thankful to Haimano Bizuneh, Marta Wondimu, Addisalem Yosef and Yegile G/Mariam, School of Plant Sciences, Plant Protection Program, Haramaya University, for their assistance in laboratory works. We thank Holleta Agricultural Research Center for accessing us chrysanthemum flower collections.

\section{References}

1. Torres AM, Román B, Avila CM, Satovic Z, Rubiales D, et al. (2006) Faba bean breeding for resistance against biotic stresses: Towards application of marker technology. Euphytica 147: 67-80.

2. Sahile S, Sakhuja PK, Fininsa C, Ahmed S (2011) Potential antagonistic fungal species from Ethiopia for biological control of chocolate spot disease of faba bean. African Crop Science Journal 19: 213-225

3. Bendahmane BS, Mahiout D, Benzohra IE, Benkada MY (2012) Antagonism of three Trichoderma Species against Botrytis fabae and B. cinerea, the causal agents of chocolate spot of faba bean (Vicia faba L.) in Algeria. World Applied Sciences Journal 17: 278-283.

4. Mussa J, Gorfu D, Keneni G (2008) Procedures of faba bean improvement through hybridization. Technical Manual No. 21, Ethiopian Institute of Agricultural Research. Addis Ababa, Ethiopia. 
Citation: Terefe H, Fininsa C, Sahile S, Tesfaye K (2015) Effect of Temperature on Growth and Sporulation of Botrytis fabae, and Resistance Reactions of Faba Bean against the Pathogen. J Plant Pathol Microb 6: 285. doi:10.4172/2157-7471.1000285

5. Dereje G, Tesfaye B (1993) Faba bean diseases in Ethiopia. In: Asfaw T, Geletu B, Saxena MC, Solh MB (eds) Cool-season food legumes of Ethiopia. Proceedings of the 1 st 5 national cool-season food legumes review conference, 16-20 December, 1993. Addis Ababa, Ethiopia.

6. Stoddard FL, Nicholas AH, Rubiales D, Thomas J, Villegas-Fernández AM (2010) Integrated pest management in faba bean. Field Crops Research 115: 308-318.

7. Tivoli B, Baranger A, Avila CM, Banniza S, Barbetti M, et al. (2006) Screening techniques and sources of resistance to foliar diseases caused by major necrotrophic fungi in grain legumes. Euphytica 147: 223-253.

8. Endale H, Gezahegn G, Tadesse S, Nigussie T, Beyene B, et al. (2014) Faba bean gall: a new threat for faba bean (Vicia faba) production in Ethiopia. Advances in Crop Science and Technology 2: 1-5.

9. Dereje G, Yaynu H (2001) Yield loss of crops due to plant diseases in Ethiopia Pest Management Journal of Ethiopia 5: 55-67.

10. Sahile S, Chemeda F, Sakhuja PK, Seid A (2010) Yield loss of faba bean (Vicia faba) due to chocolate spot (Botrytis fabae) in sole and mixed cropping systems in Ethiopia. Archives of Phytopathology and Plant Protection 43: 1144-1159.

11. Villegas-Fernández AM, Sillero JC, Rubiales $D$ (2011) Screening faba bean for chocolate spot resistance: evaluation methods and effects of age of host tissue and temperature. European Journal of Plant Pathology.

12. Dixon GR (2012) Climate change - impact on crop growth and food production, and plant pathogens. Canadian Journal of Plant Pathology 34: 362-379.

13. Webb KM, Oña I, Bai J, Garrett KA, Mew T, et al. (2010) A benefit of high temperature: increased effectiveness of a rice bacterial blight disease resistance gene. New Phytol 185: 568-576.

14. Sillero JC, Morenoa MT, Rubiales D (2000) Characterization of new sources of resistance to Uromyces viciae-fabae in a germplasm collection of Vicia faba. Plant Pathology 49: 389-395.

15. Singh D, Yadav DK, Sinha S, Choudhary G (2014) Effect of temperature, cultivars, injury of root and inoculums load of Ralstonia solanacearum to cause bacterial wilt of tomato. Archives of Phytopathology and Plant Protection 47: 1574-1583.

16. Griffiths E, Amin SM (1977) Effects of Botrytis fabae infection and mechanical defoliation on seed yield of field beans (Vicia faba). Annals of Applied Biology 86: 359-367

17. Saber HA, Revri R, Abdallah HM (2000) Faba bean (Vicia faba L.): cultural practices and integrated pest management.

18. Dereje G (1993) Studies on the epidemiology of chocolate spot (Botrytis fabae Sard.) of faba bean (Vicia faba L.). M.Sc. Thesis, Alemaya University of Agriculture. Alemaya, Ethiopia. pp. 30-70.

19. Harrison JG (1984) Effect of humidity on infection of field bean leaves by Botrytis fabae and germination of conidia. Transactions of the British Mycological Society $82: 245-248$

20. Harrison JG (1988) The biology of Botrytis spp. on Vicia beans and chocolate spot disease-a review. Plant Pathology 37: 168-201.

21. Bouhassan A, Sadiki M, Tivoli B, Portapuglia A (2004) Influence of growth stage and leaf age on expression of the components or partial resistance of faba bean to Botrytis fabae Sard. Phytopathologia Mediterranea 43: 318-324.

22. Bouhassan A, Sadiki M, Tivoli B, El Khiati N (2003) Analysis by detached leaf assay of components of partial resistance of faba bean (Vicia faba L.) to chocolate spot caused by Botrytis fabae Sard. Phytopathologia Mediterranea 42: 183-190.

23. Garrett KA, Dendy SP, Frank EE, Rouse MN, Travers SE (2006) Climate change effects on plant disease: genomes to ecosystems. Annu Rev Phytopathol 44 489-509.

24. Bouhassan A, Sadiki M, Tivoli B (2007) Effets de la temperature et de la dose de la inoculum sur les composantes de la resistance partielle de la fève au Botrytis fabae Sard. Acta Botanica Gallica 154: 53-62.

25. Brasier CM, Webber JF (1987) Positive correlation between in vitro growth rate and pathogenesis in Ophiostoma ulmi. Plant Pathology 36: 462-466.

26. ICARDA (International Center for Agricultural Research in the Dry Areas), 1986. Screening techniques for disease resistance in faba beans. International Center for Agricultural Research in the Dry Areas (ICARDA), Aleppo, Syria.
27. Zakrzewska E (2004) Reaction of morphological types of faba bean to infection with Ascochyta fabae Speg. and Botrytis fabae Sard. Plant Breeding and Seed Science 49: 3-7

28. Hmouni A, Hajlaoui MR, Mlaiki A (1996) Resistance de Botrytis cinerea aux benzimidazoles et aux dicarboximides dans les cultures de tomate en Tunisie. OEPP/EPPO Bulletin 26: 697-705.

29. Madden LV, Hughes G (1995) Plant disease incidence: distributions, heterogeneity, and temporal analysis. Annu Rev Phytopathol 33: 529-564.

30. Ding G, Xung L, Oifang G, Pingxi L, Dazaho Y, et al. (1993) Evaluation and screening of faba bean germoplasm in China. Fabis Newsletter 32: 8-10.

31. Wheeler BEJ (1969) An introduction to plant diseases. Wiley and Sons, London.

32. Pefoura AM, Ouamba AJK, Nkenfou C, Nguidjo O, Dongmo R (2007) Influence of the temperature on radial growth and sporulation of Trachysphaera fructigena, causal agent of the Musa cigar end rot disease. African Crop Science Conference Proceedings 8: 849-852.

33. Ramirez ML, Chulze SN, Magan N (2004) Impact of osmotic and matric wate stress on germination, growth, mycelial water potentials and endogenous accumulation of sugars and sugar alcohols in Fusarium graminearum. Mycologia 96: 470-478.

34. Berger RD, Filho AB, Amorim L (1997) Lesion expansion as an epidemic component. Phytopathology 87: 1005-1013.

35. SAS Institute (2001) SAS/STAT Users Guide, Version 8.2. SAS Institute Inc. Cary, NC, USA.

36. Gomez KA, Gomez AA (1984) Statistical procedures for agricultural research. (2ndedn, John Wiley and Sons Inc., New York.

37. Gaston TNR, Appolinaire LJ, Jean MCP, Ajong FD (2014) Effect of different $\mathrm{pH}$ and temperature levels on in vitro growth and sporulation of Phytophthora colocasiae, taro leaf blight pathogen. International Journal of Agronomy and Agricultural Research 4: 202-206.

38. Gupta V, Sharma AK (2013) Assessment of optimum temperature of Trichoderma harzianum by monitoring radial growth and population dynamics in different compost manures under different temperature. Octa Journal of Biosciences 1: 151-157.

39. Fernandez JG, Fernandez-Baldo MA, Sansone G, Calvente V, Benuzzi D, et al. (2014) Effect of temperature on the morphological characteristics of Botrytis cinerea and its correlated with the genetic variability. Journal of Coastal Life Medicine 2: 543-548.

40. Sehajpal PK, Singh PJ (2014) Effect of temperature on growth, sporulation and sclerotial formation of the fungus Botrytis gladiolorum timm. in different culture media and standardization of inoculum load of the fungus for generation of disease. International Journal of Research 1: 772-779.

41. Kim YK, Xiao CL, Rogers JD (2005) Influence of culture media and environmental factors on mycelial growth and pycnidial production of Sphaeropsis pyriputrescens. Mycologia 97: 25-32.

42. Fernando THPS, Jayasinghe CK, Wijesundera RLC, Siriwardane D (2012) Some factors affecting in vitro production, germination and viability of conidia of Corynespora cassiicola from Hevea brasiliensis. Journal of the National Science Foundation of Sri Lanka 40: 241-249.

43. Tu JC (1992) Colletotrichum lindemuthianum on bean: population dynamics of the pathogen and breeding for resistance. In: Bailey JA, Jeger MJ (eds) Colletotrichum: Biology, Pathology and Control. Redwood Press, Ltd., Melksham, England, pp. 203-224.

44. Makowski RMD (1993) Effect of inoculum concentration, temperature, dew period and plant growth stage on disease of round leaved mallow and velve leaf by Colletotrichum gloeosporioides f.sp. Malvae. Phytopathology 83: 12291234.

45. Khan M, Sinclair JB (1991) Effect of soil temperature on infection of soybean roots by sclerotia-forming isolates of Colletotrichum truncatum. Plant Disease 75: $1282-1285$.

46. Xu X-M (1999) Effects of temperature on the length of the incubation period of rose powdery mildew (Sphaerotheca pannosa var. rosae). European Journal of Plant Pathology 105: 13-21.

47. Xu X-M, Robinson JD (2000) Effects of temperature on the incubation and latent periods of hawthorn powdery mildew (Podosphaera clandestina). Plant Pathology 49: 791-797. 
Citation: Terefe H, Fininsa C, Sahile S, Tesfaye K (2015) Effect of Temperature on Growth and Sporulation of Botrytis fabae, and Resistance Reactions of Faba Bean against the Pathogen. J Plant Pathol Microb 6: 285. doi:10.4172/2157-7471.1000285

48. Kuruppu PU, Schneider RW (2001) Temperature effects on development of aerial blight in soybean. Phytopathology $91:$ S51.

49. Pedersen EA, Morrall RAA (1994) Effects of cultivar, leaf wetness duration, temperature, and growth stage on infection and development of Ascochyta blight in lentil. Phytopathology 84: 1024-1030.

50. Shew BB, Beute MK, Wynne JC (1988) Effects of temperature and relative humidity on expression of resistance to Cercosporidium personatum in peanut. Phytopathology 78: 493-498.

51. Chongo G, Bernier CC (2000) Effects of host, inoculum concentration, wetness duration, growth stage, and temperature on anthracnose of lentil. Plant Disease 84: 544-548.

52. Coakley SM, Scherm H, Chakraborty S (1999) Climate change and plan disease management. Annu Rev Phytopathol 37: 399-426.

53. Stoddard FL, Nicholas AH, Rubiales D, Thomas J, Villegas-Fernandez AM (2010) Integrated pest management in faba bean. Field Crops Research 115: 308-318.
54. Gilles T, Kennedy R (2003) Effects of an Interaction between Inoculum Density and Temperature on Germination of Puccinia allii Urediniospores and Leek Rust Progress. Phytopathology 93: 413-420.

55. Leandro LF, Gleason ML, Nutter FW, Wegulo SN, Dixon PM (2003) Influence of Temperature and Wetness Duration on Conidia and Appressoria of Colletotrichum acutatum on Symptomless Strawberry Leaves. Phytopathology 93: $513-520$.

56. Christiansen MN, Lewis CF (1982) Breeding plants for less favorable environments. Wiley, New York.

57. Fetch TGJr (2006) Effect of temperature on the expression of seedling resistance to Puccinia graminis $\mathrm{f}$. sp. avenae in oat. Canadian Journal of Plant Pathology 28: 558-565.

58. Kaul K, Shaner G (1989) Effect of temperature on adult-plant resistance to lea rust in wheat. Phytopathology 79: 391-394. 